\title{
Selenium protects rice plants from water deficit stress
}

\author{
Fabrício Ribeiro Andrade ${ }^{\mathrm{a}}$, Geanderson Nascimento da Silva ${ }^{\mathrm{b}}$, Karina Carvalho Guimarães ${ }^{\mathrm{c}}$, \\ Herlon Bruno Ferreira Barreto ${ }^{\mathrm{d}}$, Kamila Rezende Dázio de Souza ${ }^{\mathrm{e}}$, \\ Luiz Roberto Guimarães Guilherme ${ }^{\mathrm{a}}$, Valdemar Faquin ${ }^{\mathrm{a}}$, André Rodrigues dos Reis ${ }^{\mathrm{f}, *}$ \\ a Department of Soil Science, Federal University of Lavras, Postal Code 3037, 37200-000 Lavras, MG, Brazil \\ ${ }^{\mathrm{b}}$ Federal Institute of Education, Science and Technology of Sertão of Pernambuco, Postal Code 56304-060, Petrolina, PE, Brazil \\ ${ }^{\mathrm{c}}$ Department of Food Science, Federal University of Lavras, Postal Code 3037, 37200-000 Lavras, MG, Brazil \\ d Department of Engineering, Federal University of Lavras, Postal Code 3037, 37200-000 Lavras, MG, Brazil \\ e Department of Biology, Federal University of Lavras, Postal Code 3037, 37200-000 Lavras, MG, Brazil \\ ${ }^{\mathrm{f}}$ School of Science and Engineering, São Paulo State University - UNESP, Postal Code 17602-496, Tupã, SP, Brazil
}

\section{A R T I C L E I N F O}

\section{Keywords:}

Agronomic biofortification

Sodium selenate

Food composition

Antioxidant enzymes

Abiotic stress

\begin{abstract}
A B S T R A C T
Selenium (Se) is essential to humans and animals due to its antioxidant properties. Although it is not considered an essential nutrient for higher plants. Many studies show that Se in low concentrations (up to $0.5 \mathrm{mg} \mathrm{kg}^{-1}$ ) provides beneficial effects to non-hyperaccumulating plants by participating in antioxidant defense systems and enhancing tolerance to abiotic stress. Therefore, this study aimed to evaluate the effects of Se application rates on rice plants under different soil water conditions. The experiment was conducted on an Oxisol using four Se rates $\left(0,0.5,1.0\right.$ and $\left.2.0 \mathrm{mg} \mathrm{kg}^{-1}\right)$ and two soil water conditions (irrigated and water deficit). Selenium application via soil up to $0.5 \mathrm{mg} \mathrm{kg}^{-1}$ increased the plant height, chlorophyll index, sulfur and copper accumulation in shoots, carbon dioxide assimilation, superoxide dismutase (EC 1.15.1.1) activity and decreased the hydrogen peroxide concentration in rice leaves. The accumulation of Se in shoot biomass and Se concentration in seeds increased linearly with the applied rates. Water deficit strongly decreased the plant growth and yield. However, rice plants treated with Se showed higher net photosynthesis, water use efficiency and antioxidant system. This study provides useful information about the roles of Se in protecting rice plants from water deficit stress.
\end{abstract}

\section{Introduction}

Cultivated crops are frequently exposed to adverse conditions that affect their growth and productivity. Among the various types of environmental stress, drought is considered the most devastating because of crop yield losses, which can reach billions of dollars annually worldwide (Lambers et al., 2008; Tardieu et al., 2014; Aon, 2015). It is estimated that by 2050 , when the world population is expected to reach 9.7 billion people, approximately $49 \%$ of the global grain production will be cultivated in regions affected by water deficit (Rosegrant, 2016).

Rice (Oryza sativa L.) is the second most cultivated cereal in the world and the main food source for more than half of the world population (Reis et al., 2018). Approximately 75\% of rice production worldwide comes from planting in an irrigated and/or flooded system
(FAO, 2017). However, these cultivated area expansions are limited due to strong impacts on environmental problems (Sander et al., 2014). Therefore, upland rice cultivation tends to expand into arid regions, where dry spells are more consistent. These regions are characterized by long periods of soil water deficit due to interruptions in rainfall during the rainy season (Joy et al., 2015).

Water deficit reduces soil water potential. This reduction has direct implications for transpiration, photosynthesis, leaf temperature, stomatal opening and antioxidant metabolism, all of which affect the growth, development and especially the yield of economically important crops (Nawaz et al., 2015; Reis et al., 2015). Application of selenium (Se) can increase growth and minimize the effects of abiotic stresses (e.g., drought, salinity, high temperatures and potentially toxic element) in plants (Djanaguiraman et al., 2010; Kumar et al., 2012;

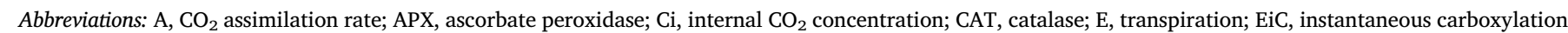

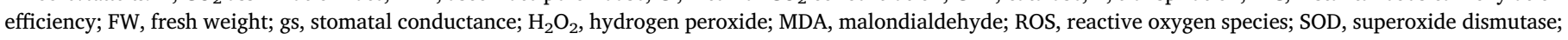
WUE, water use efficiency

* Corresponding author.

E-mail address: andre.reis@unesp.br (A.R.d. Reis). 
Nawaz et al., 2015; Jiang et al., 2017; Reis et al., 2017, 2018). There are conclusive evidences of Se deficiency in Brazilian soils (Reis et al., 2018; Silva et al., 2018). Selenium variation in Brazilian soils range from 10 to $150 \mu \mathrm{g} \mathrm{kg}^{-1}$ (Reis et al., 2017). Therefore, Se supplementation is needed in order to reduce The harmful effects on plant metabolism and physiology caused by drought stress can be decreased by Se supplementation. Selenium increases the activity of antioxidant enzymes and reduces both the generation of reactive oxygen species (ROS) and the lipid peroxidation rates in the leaf cell tissue (Habibi, 2013; Nawaz et al., 2015; Mostofa et al., 2017; Reis et al., 2018).

An increase in $\mathrm{CO}_{2}$ assimilation rate and stomatal conductance is promoted by application of Se in wheat (Triticum aestivum L.) and barley (Hordeum vulgare L.) plants exposed to drought stress (Habibi, 2013; Nawaz et al., 2015). Similarly, in olive (Olea europaea L.) under water stress, foliar applications of Se can increase photosynthesis, regulate the water status of trees and maintain a sufficiently high level of leaf water content in plants (Proietti et al., 2013). Yao et al. (2009) observed significant increases in root activity, catalase activity and chlorophyll concentration as well as decreased malondialdehyde concentration in wheat seedlings subjected to Se application under drought stress.

Therefore, studies that demonstrate the positive effects of Se application on rice plants under water deficit conditions are highly relevant. This study aimed to validate the effects of Se doses applied to the soil under two soil water conditions on the growth, yield, antioxidant system and nutritional quality status of rice plants.

\section{Materials and methods}

\subsection{Experimental design and rice cultivation}

The experiment was conducted in a greenhouse from July to December 2014 at the Soil Science Department of Federal University of Lavras, Brazil. Pots with $4 \mathrm{~kg}$ of Oxisol (clay textured) collected from the $0-0.20$-m layer were used. The soil was air-dried, sieved using a 4$\mathrm{mm}$ mesh and characterized for its major chemical and physical properties according to the methodology suggested by EMBRAPA (1997). The chemical and physical properties as follows: $\mathrm{pH}-\mathrm{H}_{2} \mathrm{O}=5.1$; organic matter $=46 \mathrm{~g} \mathrm{~kg}^{-1}$; $\mathrm{P}$ (Mehlich-1) $=0.84 \mathrm{mg} \mathrm{kg}^{-1} ; \mathrm{K}=1.7$ mmolc dm ${ }^{-3} ; \mathrm{Ca}=1.5 \mathrm{cmolc} \mathrm{dm}^{-3} ; \mathrm{Mg}=0.4 \mathrm{cmolc} \mathrm{dm}^{-3} ; \mathrm{Al}=0.5$ cmolc $\mathrm{dm}^{-3} ; \mathrm{HAl}=6.3 \mathrm{cmolc} \mathrm{dm}^{-3}$; P-rem $=11.37 \mathrm{mg} \mathrm{L}^{-1}$; clay $=710 \mathrm{~g} \mathrm{~kg}^{-1}$; silt $=140 \mathrm{~g} \mathrm{~kg}^{-1}$; and sand $=150 \mathrm{~g} \mathrm{~kg}^{-1}$. The content of Se was $0.2 \pm 0.04 \mathrm{mg} \mathrm{kg}^{-1}$, which was determined after soil digestion according the USEPA 3051A method (USEPA, 1998).

Based on soil chemical analysis, liming was carried out to raise the base saturation to $60 \%$ using $\mathrm{CaCO}_{3}$ and $\mathrm{MgCO}_{3}$ at a ratio of $4: 1$. After 30 days of soil incubation with a humidity close to $60 \%$ of the total pore volume (TPV), doses of Se (sodium selenate, Sigma-Aldrich, Saint Louis, USA) were applied to the soil. Each pot received a macronutrient fertilizer containing: $80 \mathrm{mg}$ of $\mathrm{N}, 250 \mathrm{mg}$ of $\mathrm{P}, 90 \mathrm{mg}$ of $\mathrm{K}$, and $50 \mathrm{mg}$ of $\mathrm{S}$ $\mathrm{kg}^{-1}$ soil. Micronutrient applications consisted of $0.5 \mathrm{mg}$ of $\mathrm{B}, 1.5 \mathrm{mg}$ of $\mathrm{Cu}, 0.1 \mathrm{mg}$ of Mo and $5.0 \mathrm{mg}$ of $\mathrm{Zn} \mathrm{kg}^{-1}$ soil.

Afterward, 15 rice seeds (O. sativa L. cv. IAC 202) were sown per pot, and nine days after seedling emergence, the rice seedlings were thinned three plants per pot. In addition, during the rice cultivation period, blanket fertilizations of $473 \mathrm{mg}$ of $\mathrm{N}$ and $436 \mathrm{mg}^{\circ} \mathrm{K} \mathrm{kg}^{-1}$ soil were carried out and divided into five applications.

The experiments were set up as a completely randomized design in a $4 \times 2$ factorial scheme with four Se doses $\left(0,0.5,1.0\right.$ and $2.0 \mathrm{mg} \mathrm{kg}^{-1}$ Se) and two soil water conditions (irrigated and water deficit), with four replicates, during the beginning of the reproductive stage. The control treatment consisted of maintaining the soil near field capacity, and water deficit treatment involved maintaining the soil at approximately $-50 \mathrm{kPa}$, as determined by for rice cultivation. Each experimental unit consisted of two pots: one used for the analyses performed (gas exchange, antioxidant system, SPAD index growth and nutrition) at the end of water deficit, and the other was used only at seed harvest.
To monitor soil water tension, tensiometers were installed at a 0.15 $\mathrm{m}$ depth in each experimental plot, and the replenishment of evapotranspired water was performed based on the tensiometric reading, which was performed twice daily at 9:00 and 16:00 h. Appropriate water replenishment was used to determine water retention curves for the soil. From emergence to the flag leaf/collar-formation stage, field capacity was maintained by soil moisture in all pots.

In the flag leaf/collar-formation stage, water deficit treatments were applied to the respective pots, and soil water potential was maintained at $-50 \mathrm{kPa}$ for 14 days to simulate dry spells; samples not subjected to water deficit were maintained under normal irrigation conditions. At the end of this period, irrigation to plants under water stress was restored to field capacity until harvest.

\subsection{Gas exchange measurements}

On the 14th day of water stress at the end of water deficit period, which coincided with the initial panicle exsertion stage of rice, gas exchange evaluations were performed using a portable infrared gas analyzer (Infra Red Gas Analyzer - IRGA, brand LI-COR Biosciences, model LICOR 6400). The $\mathrm{CO}_{2}$ assimilation rate expressed by area $(A-$ $\left.\mu \mathrm{mol} \mathrm{CO}_{2} \mathrm{~m}^{-2} \mathrm{~s}^{-1}\right)$, stomatal conductance $\left(g s-\mathrm{mol} \mathrm{H}_{2} \mathrm{O} \mathrm{m} \mathrm{m}^{-2} \mathrm{~s}^{-1}\right)$, transpiration $\left(E-\mathrm{mmol} \mathrm{H}_{2} \mathrm{O} \mathrm{m}{ }^{-2} \mathrm{~s}^{-1}\right)$ and internal $\mathrm{CO}_{2}$ concentration in the substomatal chamber $\left(\mathrm{Ci}-\mu \mathrm{mol} \mathrm{CO} \mathrm{Col} \mathrm{air}^{-1}\right)$ were obtained. With those data, an estimation of both instantaneous carboxylation efficiency $\left[\mathrm{EiC},\left(\mathrm{A} / \mathrm{Ci}-\mathrm{mol} \mathrm{air}^{-1}\right)\right]$ and water use efficiency [WUE, $(A / E$ - $\left.\mu \mathrm{mol} \mathrm{CO} \mathrm{CO}_{2} \mathrm{mmol}^{-1} \mathrm{H}_{2} \mathrm{O}\right)$ ] were determined. Readings were performed on a clear day between 9:00 and 11:00 a.m. using the flag leaf as a pattern, including the last fully developed leaf. The photosynthetically active radiation (PAR) was standardized to an artificial saturating light of $1000 \mu \mathrm{mol} \mathrm{m}^{-2} \mathrm{~s}^{-1}$ and an ambient $\mathrm{CO}_{2}$ concentration. The average relative humidity was $30 \%$, and the ambient temperature was between 35 and $42{ }^{\circ} \mathrm{C}$.

\subsection{Biometric and chlorophyll meter measurements}

Using three leaves per pot on the same day, the SPAD index was determined using a portable chlorophyll meter (SPAD-502, KonicaMinolta, Japan). After SPAD readings, leaves were collected and immediately conditioned in liquid nitrogen, after which they were stored at $-80^{\circ} \mathrm{C}$ for biochemical analyses. After all these determinations at end of the water deficit period, the height of plants at that time was obtained by measuring from the plant base to the end of last fully expanded leaf. The shoots and roots of plants were collected and dried in a forced-air oven for $72 \mathrm{~h}$ in order to obtain and determine the dry biomass and root/shoot relation. The other post treatments aimed at seed production were conducted until the cycle ended, after which the grains were harvested, dried in a forced-air oven, and weighed to obtain the dry mass of seeds in each pot.

\subsection{Extraction and quantification of antioxidant enzymes}

To quantify antioxidant enzyme activity in leaves, an extract was obtained by maceration of $0.1 \mathrm{~g}$ of leaves in liquid nitrogen. The extract was then added to an extraction buffer solution containing $0.1 \mathrm{M}$ potassium phosphate ( $\mathrm{pH} 7.8$ ), 0.1 mM EDTA (pH 7.0), $0.01 \mathrm{M}$ ascorbic acid and $22 \mathrm{mg}$ of polyvinylpyrrolidone (PVPP) (Biemelt et al., 1998). The supernatant was then collected and used for enzymatic analyses of superoxide dismutase (SOD), catalase (CAT) and ascorbate peroxidase (APX).

\subsubsection{Superoxide dismutase (SOD; EC 1.15.1.1)}

SOD activity was evaluated by the ability of the enzyme to inhibit the photoreduction of nitroblue tetrazolium (NBT), as proposed by Giannopolitis and Ries (1977). An aliquot of the supernatant was added to an incubation medium composed of $50 \mathrm{mM}$ potassium phosphate $(\mathrm{pH}$ 
7.8), $14 \mathrm{mM}$ methionine, $0.1 \mu \mathrm{M}$ EDTA, $75 \mu \mathrm{M}$ NBT and $2 \mu \mathrm{M}$ riboflavin. Tubes with reaction media and samples were illuminated for $7 \mathrm{~min}$ with a 20 -W fluorescent lamp. For the control, the same reaction medium was illuminated without the sample present. Readings were performed at $560 \mathrm{~nm}$. One unit of SOD corresponds to the amount of enzyme capable of inhibiting the photoreduction of NBT by $50 \%$ under assay conditions.

\subsubsection{Catalase (CAT; EC 1.11.1.6)}

CAT was evaluated according to method described by Havir and McHale (1987), in which an aliquot of enzyme extract was added to an incubation medium containing $100 \mathrm{mM}$ potassium phosphate $(\mathrm{pH} 7.0$ ) that was previously incubated at $30^{\circ} \mathrm{C}$. Immediately prior to absorbance readings, $12.5 \mathrm{mM}$ hydrogen peroxide was added to trigger this reaction. CAT activity was determined by measuring the consumption of hydrogen peroxide $\left(\mathrm{H}_{2} \mathrm{O}_{2}\right)$ at $240 \mathrm{~nm}$ for $3 \mathrm{~min}$. A molar extinction coefficient of $36 \mathrm{mM}^{-1} \mathrm{~cm}^{-1}$ was used for calculations.

\subsubsection{Ascorbate peroxidase (APX, EC 1.11.1.11)}

APX activity was determined by monitoring the oxidation rate of ascorbate at $290 \mathrm{~nm}$ for $3 \mathrm{~min}$. For this measurement, an aliquot of enzyme extract was added to an incubation buffer composed of $100 \mathrm{mM}$ potassium phosphate (pH 7.0) and $0.5 \mathrm{mM}$ ascorbic acid, which was previously incubated at $30^{\circ} \mathrm{C}$. Prior to measuring the oxidation rate, $0.1 \mathrm{mM} \mathrm{H}_{2} \mathrm{O}_{2}$ (Nakano and Asada, 1981) was added to the sample. A molar extinction coefficient of $2.8 \mathrm{mM}^{-1} \mathrm{~cm}^{-1}$ was used for calculations.

\subsection{Hydrogen peroxide}

Hydrogen peroxide was quantified from an extract made by macerating $0.2 \mathrm{~g}$ of leaves in liquid nitrogen. The extract was then homogenized in $1.5 \mathrm{~mL}$ of trichloroacetic acid (TCA) and centrifuged at $12,000 \mathrm{~g}$ for $15 \mathrm{~min}$ at $4^{\circ} \mathrm{C}$. Hydrogen peroxide levels were determined by measuring absorbance at $390 \mathrm{~nm}$. Aliquots of the supernatant were added to a reaction medium containing $2.5 \mathrm{mM}$ potassium phosphate buffer (pH 7.0) and $500 \mathrm{mM}$ potassium iodate (Velikova et al., 2000). Quantification of $\mathrm{H}_{2} \mathrm{O}_{2}$ was performed based on a standard curve with known concentrations of $\mathrm{H}_{2} \mathrm{O}_{2}$.

\subsection{Lipid peroxidation}

Lipid peroxidation was determined by the quantification of thiobarbituric acid reactive species (TBA), as described by Buege and Aust (1978). A total of $0.2 \mathrm{~g}$ of leaves was macerated in liquid nitrogen and $20 \%$ PVPP (w/v), which was homogenized in $0.1 \%(w / v)$ TCA. The homogenate was then centrifuged at $10,000 \mathrm{~g}$ for $10 \mathrm{~min}$. Aliquots of the supernatant were added to a reaction medium containing $0.5 \%(\mathrm{w} / \mathrm{v})$ TBA and $10 \%(\mathrm{w} / \mathrm{v})$ TCA, after which the samples were incubated at $95^{\circ} \mathrm{C}$ for $30 \mathrm{~min}$. The reaction was stopped by cooling the samples on ice. Absorbance was measured using a spectrophotometer at $535 \mathrm{~nm}$ and $600 \mathrm{~nm}$, and the results were expressed in nanomoles of malondialdehyde (MDA) per milligram of fresh weight (FW).

\subsection{Chemical analysis of plant tissue}

Shoot dry biomass and grains were ground in a Willey mill equipped with a 40-mesh screen. Subsequently, in the aerial parts of plants, chemical analyses were performed to determine macro and micronutrient concentration in accordance with the methodology described by Malavolta et al. (1997). A turbidimetric method was used to quantify total sulfur in plant tissue was previously described by Malavolta et al. (1997). Se concentration in these tissues, $0.5 \mathrm{~g}$ of tissue was used for perchloric-nitric digestion. Extracts sat for $15 \mathrm{~min}$, after which $10 \mathrm{~mL}$ of deionized water was added. For analytical quality control, analyses were certified using the BCR 402 (white clover) standard (Sigma-
Aldrich). Blank and certified reference samples were analyzed along with the digestion of every batch, which presented a minimum of $95 \%$ $(\mathrm{n}=7)$ recovery. The extracts were measured $\mathrm{Ca}, \mathrm{Mg}, \mathrm{K}, \mathrm{Cu}, \mathrm{Fe}, \mathrm{Mn}, \mathrm{Se}$ and $\mathrm{Zn}$ using atomic absorption spectroscopy with electrothermal atomization in a graphite furnace (Perkin Elmer, model AA-analyst 800, Midland, Canada) as previously described by Silva Junior et al. (2017).

\subsection{Statistical analysis}

When all data sets were considered, normality was analyzed using the Anderson-Darling test, and homoscedasticity was verified using the variance equation test (or the Levene test). The data obtained for each variable were subjected to the analysis of variance ( $\mathrm{p} \leq 0.05$ ), and the factors were compared using the Scott-Knott test in R 3.2.3 statistical program (R Development Core Team, 2011).

\section{Results}

\subsection{Gas exchange and antioxidant metabolism}

Interactions ( $p \leq 0.05$ ) between soil water conditions and Se doses applied to $A, g s, E, E i C$ and WUE (Fig. 1A-F) were observed. Internal $\mathrm{CO}_{2}$ concentration (Table 1 and Fig. 1D), lipid peroxidation (Table 1), SOD activity (Fig. 2A) and $\mathrm{H}_{2} \mathrm{O}_{2}$ concentration (Table 1 and Fig. 2B) were affected $(p \leq 0.05)$ when analyzed individually by water condition and Se doses. Ascorbate peroxidase and CAT activity were not affected by soil water condition or by Se doses.

Water deficit promoted the reduction of $A, g s, E$ and EiC (Fig. 1A-C and E) by all Se doses applied, except when $g s$ were checked without Se application. For WUE estimation (Fig. 1F), the highest dose of Se $\left(2.0 \mathrm{mg} \mathrm{kg}^{-1}\right)$ enabled an increase of this variable when plants were subjected to water deficit, and these results differed from those of irrigated plants. The $\mathrm{Ci}$ increased by $16.52 \%$ in plants under water deficit (Table 1).

Application of $1.0 \mathrm{mg} \mathrm{kg}^{-1}$ Se to irrigated plants usually promoted the highest values of $A, g s, E$ and $E i C$ (Fig. $1 \mathrm{~A}-\mathrm{C}$ and E), unlike plants that did not receive Se. For WUE (Fig. 1F), there were no differences among Se doses in irrigated plants. However, at the highest dose ( $2.0 \mathrm{mg} \mathrm{kg}^{-1}$ ), there was reduction in $A, g s$, and EiC. In plants subjected to water deficit, application of Se promoted an increase in $A, E, E i C$ and WUE (Fig. 1A, C, E and F) compared to plants that did not receive Se. The $g s$ in plants subjected to water deficit did not vary with the doses of Se applied (Fig. 1B).

The $A$ and $E$ of plants under water deficit that received a dose of $1.0 \mathrm{mg} \mathrm{kg}^{-1} \mathrm{Se}$ in the soil were $76.0 \%$ and $46.2 \%$ higher than those of plants that did not receive Se (Fig. $1 \mathrm{~A}$ and $\mathrm{C}$ ). The $\mathrm{Ci}$ decreased accordingly with increasing doses of Se applied, regardless of whether plants were under water stress or not (Fig. 1D). A dose of $0.5 \mathrm{mg} \mathrm{kg}^{-1}$ Se promoted a $\mathrm{Ci}$ that was approximately $15 \%$ lower than that of plants that did not receive Se application, although the results were not different compared to those of other doses.

Unlike the results for $\mathrm{Ci}$, water deficit increased the concentrations of $\mathrm{H}_{2} \mathrm{O}_{2}$ and MDA by $19.4 \%$ and $28 \%$ in rice plants (Table 1 ), respectively. Application of $0.5 \mathrm{mg} \mathrm{kg}^{-1} \mathrm{Se}$ promoted an increase in SOD activity and a decrease in $\mathrm{H}_{2} \mathrm{O}_{2}$ concentration (Fig. 2A and B) compared to those of plants that did not receive Se regardless of the water regimen to which the rice plants were subjected.

\subsection{Biometric measurements, chlorophyll readings and nutrient accumulations}

Interactions $(p \leq 0.05)$ between the water conditions of the soil and doses of Se regarding SPAD index and the accumulation of sulfur (S) (Fig. 3A and C) were observed. Plant height and copper $(\mathrm{Cu})$ accumulation (Table 2 and Fig. 3B and D) were affected $(p \leq 0.05)$ individually by water conditions and Se doses. Dry shoot, root, overall biomass and 

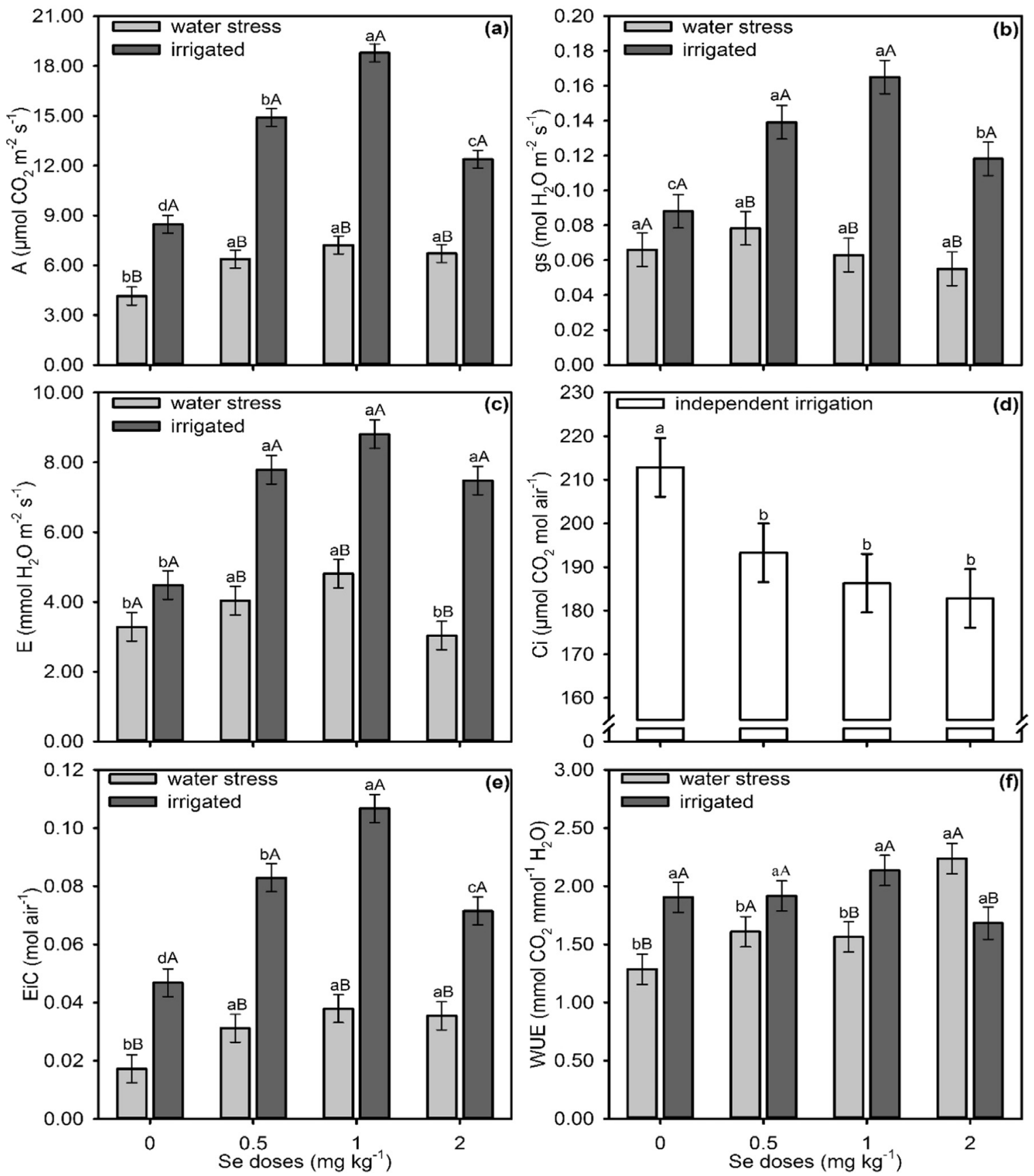

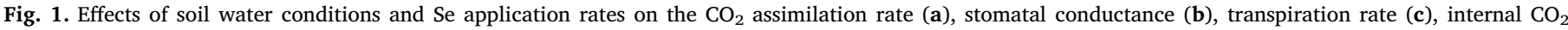

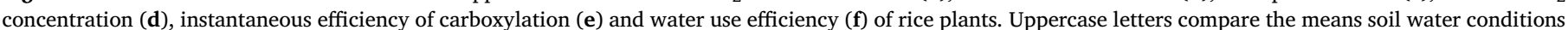

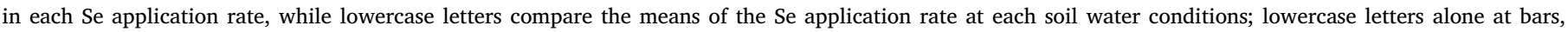

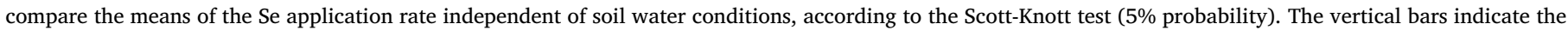
standard errors of the average values $(n=4)$.

Table 1

Effects of water conditions on internal $\mathrm{CO}_{2}$ concentration ( $\mathrm{Ci}$ ), hydrogen peroxide $\left(\mathrm{H}_{2} \mathrm{O}_{2}\right)$ and lipid peroxidation (MDA) in rice plants.

\begin{tabular}{|c|c|c|c|}
\hline Water condition & $C i\left(\mu \mathrm{mol} \mathrm{m}{ }^{-2} \mathrm{~s}^{-1}\right)$ & $\begin{array}{l}\mathrm{H}_{2} \mathrm{O}_{2}\left(\mu \mathrm{mol} \mathrm{H}{ }_{2} \mathrm{O}_{2} \mathrm{mg}^{-}\right. \\
{ }^{1} \text { FW) }\end{array}$ & $\begin{array}{l}\text { MDA (nmol mg-1 } \\
\text { FW) }\end{array}$ \\
\hline Irrigated & $179.03^{b} \pm 3.94$ & $11.84^{b} \pm 0.63$ & $82.45^{b} \pm 4.93$ \\
\hline Water deficit & $208.59^{\mathrm{a}} \pm 7.09$ & $14.69^{\mathrm{a}} \pm 0.82$ & $114.62^{\mathrm{a}} \pm 4.22$ \\
\hline
\end{tabular}

Means not sharing the same letter, a and b, differ significantly $(p<0.05$ ) within each column. \pm standard error of average values $(n=4)$. seed biomass as well as the accumulations of nitrogen $(\mathrm{N})$, phosphorus $(\mathrm{P})$, potassium $(\mathrm{K})$, calcium $(\mathrm{Ca})$, magnesium $(\mathrm{Mg})$, boron $(\mathrm{B})$, iron $(\mathrm{Fe})$, manganese $(\mathrm{Mn})$ and zinc ( $\mathrm{Zn})$ (Table 2) were affected by soil water conditions. The root/shoot ratio was not affected by soil water conditions or Se doses.

The SPAD index was lower in plants cultivated under water deficit in the absence of Se and with application $1.0 \mathrm{mg} \mathrm{kg}^{-1}$ (Fig. 3A) when compared to plants grown under normal water conditions. The highest SPAD index in irrigated plants was recorded at the Se dose of $1.0 \mathrm{mg}$ $\mathrm{kg}^{-1}$, although no difference was observed in plants that did not receive Se. When comparing the Se doses in treatments of water stress, plants that received a $0.5 \mathrm{mg} \mathrm{kg}^{-1}$ Se dose had an $8 \%$ higher SPAD 

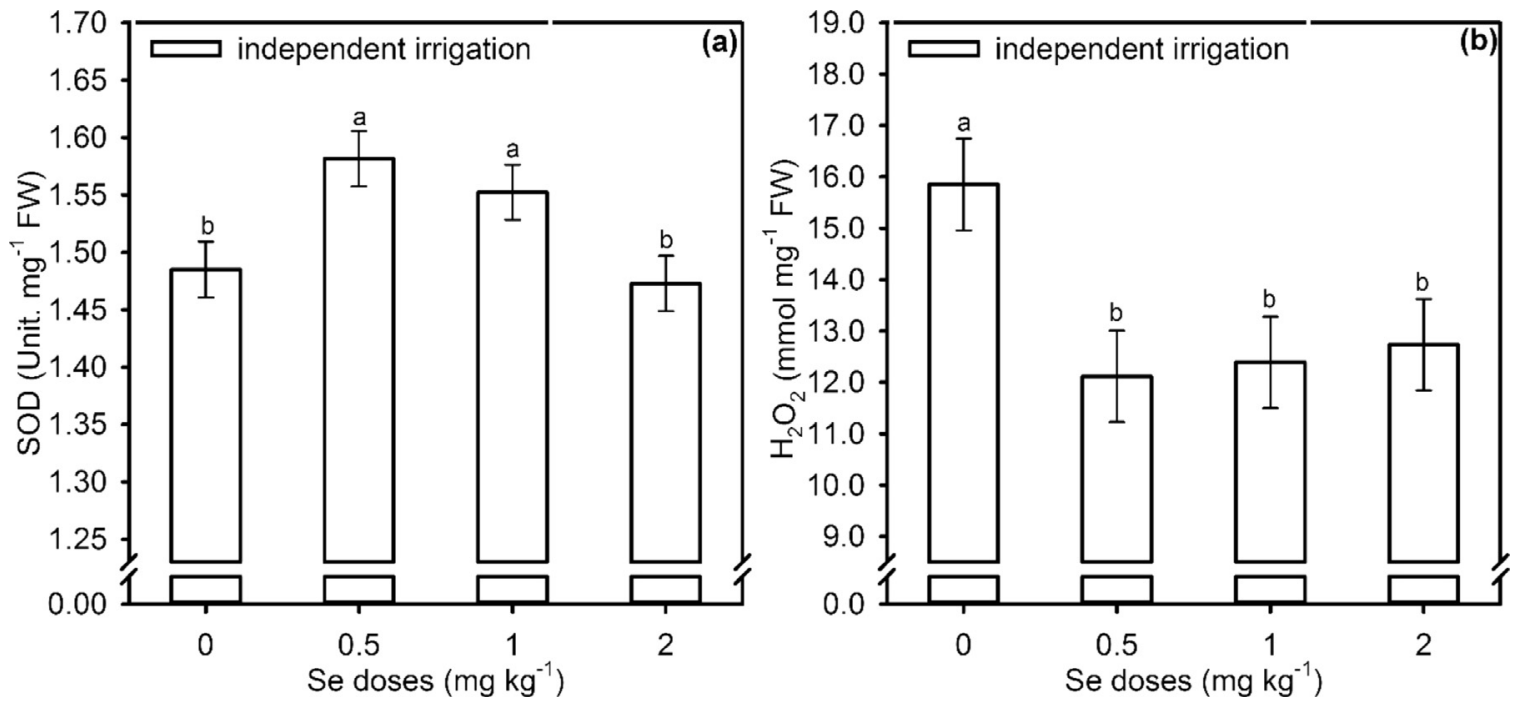

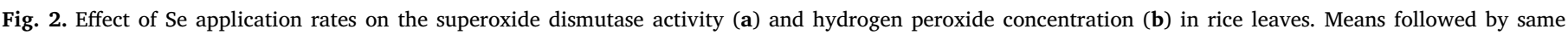

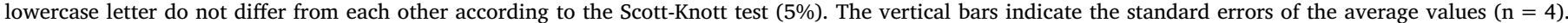
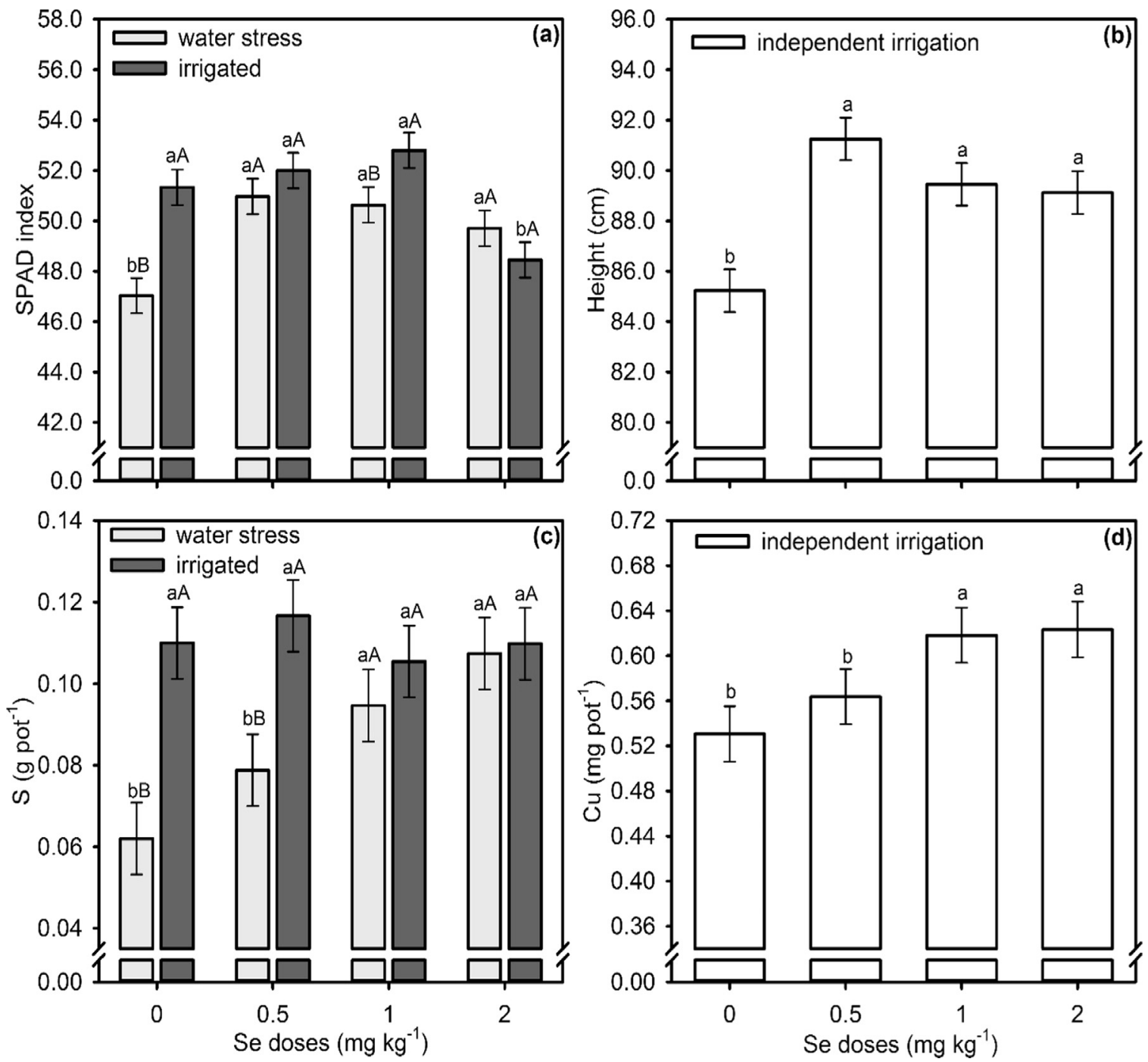

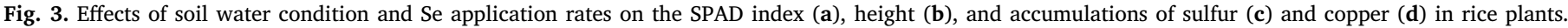

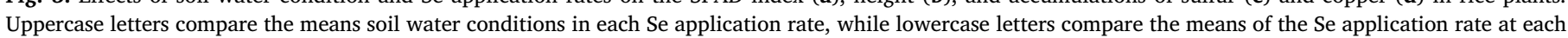

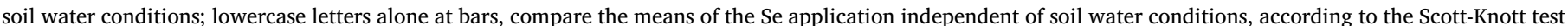
( $5 \%$ probability). The vertical bars indicate the standard errors of average values $(n=4)$. 
Table 2

Growth, grain biomass and nutrient accumulation in rice plants under different soil water conditions.

\begin{tabular}{|c|c|c|c|c|c|}
\hline \multicolumn{6}{|l|}{ Growth } \\
\hline Water condition & $\begin{array}{l}\text { Shoot dry } \\
\text { biomass }\end{array}$ & $\begin{array}{l}\text { Root dry } \\
\text { biomass }\end{array}$ & $\begin{array}{l}\text { Overall } \\
\text { dry } \\
\text { biomass } \\
\left(\mathrm{g} \mathrm{pot}^{-1}\right)\end{array}$ & $\begin{array}{l}\text { Height of } \\
\text { plants }\end{array}$ & $\begin{array}{l}\text { Grain } \\
\text { biomass }\end{array}$ \\
\hline Irrigated & $\begin{array}{l}79.25^{\mathrm{a}} \\
\pm 0.84\end{array}$ & $\begin{array}{l}60.63^{\mathrm{a}} \\
\pm 2.72\end{array}$ & $\begin{array}{r}139.88^{\mathrm{a}} \\
\pm 2.76\end{array}$ & $\begin{array}{l}93.60^{\mathrm{a}} \\
\pm 0.84\end{array}$ & $\begin{array}{l}75.26^{\mathrm{a}} \\
\pm 1.42\end{array}$ \\
\hline Water deficit & $\begin{array}{l}46.75^{\mathrm{b}} \\
\pm 0.52\end{array}$ & $\begin{array}{l}42.63^{\mathrm{b}} \\
\pm 3.31\end{array}$ & $\begin{array}{l}89.38^{\mathrm{b}} \\
\pm 3.40\end{array}$ & $\begin{array}{l}83.93^{\mathrm{b}} \\
\pm 0.77\end{array}$ & $\begin{array}{l}31.19^{\mathrm{b}} \\
\pm 1.60\end{array}$ \\
\hline \multicolumn{6}{|c|}{ Nutrient accumulation } \\
\hline Water condition & $\begin{array}{l}\mathrm{N} \\
\mathrm{g} \mathrm{pot}^{-1}\end{array}$ & $P$ & $\mathrm{~K}$ & $\mathrm{Ca}$ & $\mathrm{Mg}$ \\
\hline Irrigated & $\begin{array}{l}1.487^{\mathrm{a}} \\
\pm 0.031\end{array}$ & $\begin{array}{l}0.127^{\mathrm{a}} \\
\pm 0.005\end{array}$ & $\begin{array}{l}1.720^{\mathrm{a}} \\
\pm 0.044\end{array}$ & $\begin{array}{l}0.194^{\mathrm{a}} \\
\pm 0.011\end{array}$ & $\begin{array}{l}0.249^{\mathrm{a}} \\
\pm 0.011\end{array}$ \\
\hline Water deficit & $\begin{array}{l}1.136^{\mathrm{b}} \\
\pm 0.039\end{array}$ & $\begin{array}{l}0.083^{\mathrm{b}} \\
\pm 0.003\end{array}$ & $\begin{array}{l}1.125^{\mathrm{b}} \\
\pm 0.027\end{array}$ & $\begin{array}{l}0.149^{\mathrm{b}} \\
\pm 0.008\end{array}$ & $\begin{array}{l}0.171^{\mathrm{b}} \\
\pm 0.011\end{array}$ \\
\hline Water condition & $\begin{array}{l}\text { B } \\
\mathrm{mg} \mathrm{pot}^{-1}\end{array}$ & $\mathrm{Cu}$ & $\mathrm{Fe}$ & Mn & $\mathrm{Zn}$ \\
\hline Irrigated & $\begin{array}{l}1.097^{\mathrm{a}} \\
\pm 0.048\end{array}$ & $\begin{array}{l}0.74^{\mathrm{a}} \\
\pm 0.021\end{array}$ & $\begin{array}{l}9.81^{\mathrm{a}} \\
\pm 0.451\end{array}$ & $\begin{array}{l}84.39^{\mathrm{a}} \\
\pm 4.82\end{array}$ & $\begin{array}{l}3.48^{\mathrm{a}} \\
\pm 0.111\end{array}$ \\
\hline Water deficit & $\begin{array}{l}0.799^{\mathrm{b}} \\
\pm 0.044\end{array}$ & $\begin{array}{l}0.42^{\mathrm{b}} \\
\pm 0.013\end{array}$ & $\begin{array}{l}7.24^{\mathrm{b}} \\
\pm 0.326\end{array}$ & $\begin{array}{l}59.95^{\mathrm{b}} \\
\pm 1.75\end{array}$ & $\begin{array}{l}2.63^{\mathrm{b}} \\
\pm 0.122\end{array}$ \\
\hline
\end{tabular}

Means not sharing the same letter, a and b, differ significantly $(p<0.05)$ within each column. \pm standard error of average values $(n=4)$.

index than did control plants (Fig. 3A).

The accumulation of $S$ in plants under water stress was similar to $S$ accumulation in irrigated plants that received 1.0 and $2.0 \mathrm{mg} \mathrm{kg}^{-1} \mathrm{Se}$ (Fig. 3C). Increasing doses of Se did not cause significant accumulations of $S$ in plants under the normal water regimen. In plants subjected to water deficit, there was significant increase in $\mathrm{S}$ accumulation in rice biomass (Fig. 3C).

Plant height increased with Se doses, regardless of water conditions. The $0.5 \mathrm{mg} \mathrm{kg}^{-1}$ dose of Se the provided the highest height, which was a $6.6 \%$ increase compared to that of untreated plants (Fig. 3B). The accumulation of $\mathrm{Cu}$ in rice plants increased linearly with increasing doses of Se applied to the soil (Fig. 3D). The dose of $2.0 \mathrm{mg} \mathrm{kg}^{-1} \mathrm{Se}$ increased $\mathrm{Cu}$ accumulation in the shoot biomass by $17.5 \%$ compared to that of plants that did not receive Se application.

Water deficit in rice plants caused reductions of $41 \%, 29.6 \%$, $36.1 \%, 58.5 \%$ and $10.3 \%$ in shoot dry biomass, root dry biomass, overall dry biomass, seed production and plant height, respectively. Similarly, the accumulations of N, P, K, Ca, Mg, B, Cu, Fe, Mn and Zn decreased under water deficit conditions in rice plants (Table 2).

\subsection{Se accumulation and concentration in seeds}

Selenium accumulation in shoots (Fig. 4A) was affected ( $p \leq 0.05$ ) only by the applied doses of Se. For Se concentration in grains, interactions ( $p \leq 0.05$ ) between soil water conditions and Se doses (Fig. 4B) were observed. The accumulation of Se in the biomass of rice plants increased linearly with increasing application of Se doses regardless of water regimen (Fig. 4A). The highest accumulation of Se in the biomass $\left(2.10 \mathrm{mg} \mathrm{pot}^{-1}\right)$ was recorded in the treatment consisting of the highest dose of Se. Water deficit promoted a reduction in the Se concentration in the seeds of plants that received doses of 1.0 and $2.0 \mathrm{mg} \mathrm{kg}^{-1} \mathrm{Se}$. Selenium concentration in rice seeds increased linearly from 0 to $20.78 \mathrm{mg} \mathrm{kg}^{-1}$ under water deficit conditions and from 0 to $23.58 \mathrm{mg} \mathrm{kg}^{-1}$ under irrigated conditions (Fig. 4B).

\section{Discussion}

Our results demonstrated that water stress reduces photosynthesis, growth, nutrient absorption and rice yield. However, Se application increased $A, g s, E$ and WUE in plants under water stress. The reductions of $A, g s, E$ and $E i C$ (Fig. 1A-C and E) in plants subjected to water deficit at all doses of Se are related to the negative effects of water restriction on these variables. On the other hand, an increase in WUE at the dose of $2.0 \mathrm{mg} \mathrm{kg}^{-1} \mathrm{Se}$ (Fig. 1F) was also observed in these plants. Water deficit significantly reduces the growth of cultivated plants due to the direct influence of water deficit on various physiological and biochemical processes (R. Ahmad et al., 2016b).

Decreases in $A$ and $g s$ in plants experiencing water deficit may be due to chlorophyll degradation and fragmentation, the suppression of rubisco activity and stomatal closure (Jákli et al., 2017; Zhang et al., 2017). Transpiration is an essential process for plants during photosynthesis. A reduction in transpiration to maintain internal water balance when plants are subjected to water deficit, as described by Yan et al. (2016), was verified in this study. Zain et al. (2014) reported a decrease in $A$, $g s$ and $E$ as water deficit increased while subjecting rice plants to water deficit, which was also observed in this study.

Although water stress decreased $A, g s, E, E i C$ and WUE, Se application attenuates these reductions, which was verified in our study. This is related to the protective Se effects that minimizes damage to chloroplast structure and promotes greater activity of the electron transport system compared to the control. Nawaz et al. (2015) and Proietti et al. (2013) reported positive effects of Se application on $A, g s$ and $E$ in wheat and olive plants under both normal water and water deficit conditions.

The lowest $\mathrm{EiC}$ in plants subjected to water stress in the present study is associated with a limitation in $\mathrm{CO}_{2}$ assimilation (Fig. $1 \mathrm{~A}$ ) caused by stomatal closure (Fig. 1B). Stomatal closure is considered the main cause of decreasing rates of photosynthesis in C3 plants subjected to moderate water deficit (Flexas and Medrano, 2002). However, under more severe stress conditions, $\mathrm{Ci}$ increases, which indicates a predominance of non-stomatal limitations to photosynthesis, as reported by Mafakheri et al. (2010).

The increase in WUE with increasing Se doses in rice plants under water deficit is related to the activation of osmotically active compounds by this element. Nawaz et al. (2016) reported the accumulation of osmotically active molecules in corn (Zea mays L.) under conditions of water restriction associated with Se applications, which resulted in the greatest WUE by the plant.

The highest concentrations of $\mathrm{H}_{2} \mathrm{O}_{2}$ and lipid peroxidation (Table 1) in rice plants subjected to water deficit could be related to the disturbance between generation and extinction of reactive oxygen species. This is because water stress reduces the water content in plants, which leads to the degradation of pigments (Fig. 3A), reduction of the photochemical phase, reduction of $\mathrm{CO}_{2}$ assimilation (Fig. 1A), breakage of homeostasis and elevation of ROS generation (Faize et al., 2011). Habibi (2013) and Zain et al. (2014) reported increases in the concentrations of lipid peroxidation and $\mathrm{H}_{2} \mathrm{O}_{2}$ in barley and rice, respectively, in plants subjected to water deficit.

An increase in SOD enzyme activity associated with decreased $\mathrm{Ci}$ and $\mathrm{H}_{2} \mathrm{O}_{2}$ in rice plants due to Se application in the present study shows the protective role of this element, as reported by Feng et al. (2012) and Yao et al. (2013). Even though SOD is not a selenoenzyme, Se increases gene expression and activity levels of the SOD enzyme. Jiang et al. (2017) reported that genes involved in SOD activation mechanisms are significantly upregulated in maize roots $24 \mathrm{~h}$ after applications of $1 \mu \mathrm{M}$ Se. Nawaz et al. (2016) reported an increase in SOD activity in corn plants under normal irrigation conditions after the addition of Se to soil.

A reduction in $\mathrm{H}_{2} \mathrm{O}_{2}$ content is related to increased SOD activity (Fig. 2A) as a result of Se application, as SOD is the first line of antioxidative defense against ROS. An increase in SOD activity after Se application provides evidence that this element may be directly involved in the extinction of superoxide $\left(\mathrm{O}_{2}^{-}\right)$and hydroxyl radicals $\left(\mathrm{OH}^{-}\right)$ in cells (Nawaz et al., 2016).

Water deficit decreased the height, biomass and grain yield of rice plants, and these changes may be related to numerous processes in the plant in which water participates, with an emphasis on maintaining 

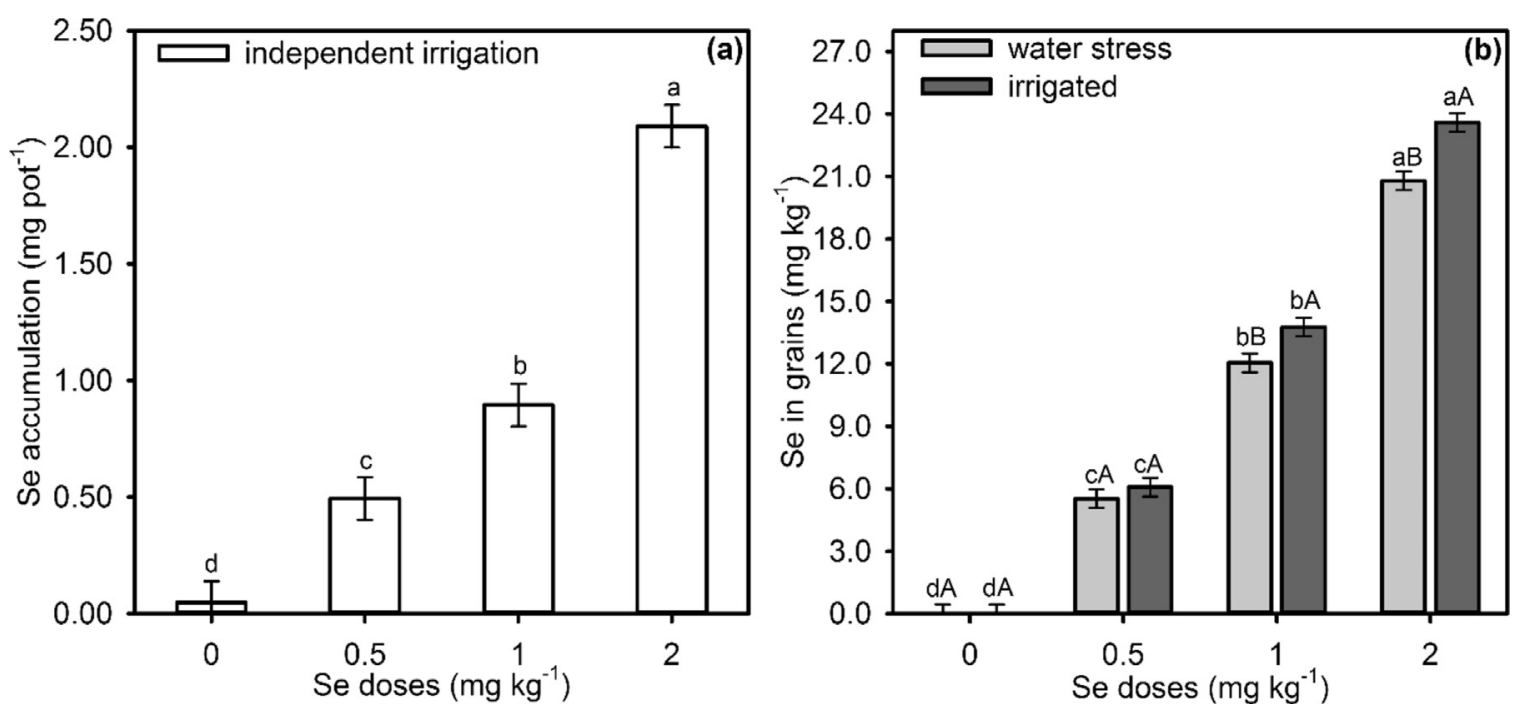

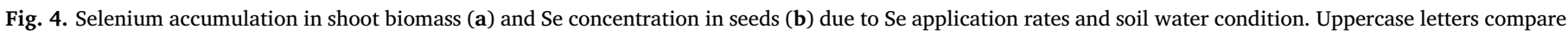

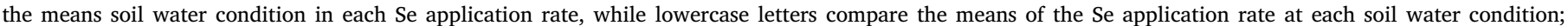

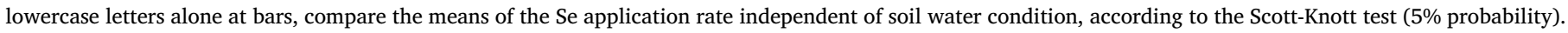
The vertical bars indicate the standard errors of average values $(n=4)$.

turgor and mitotic impairment (Jaleel et al., 2009). When water is reduced due to water deficit, turgescence severely reduces cell growth (Flexas, 2016). Water deficit affects both stretching and cell growth and inhibits cell growth rather than cell division (Jaleel et al., 2009; Shao et al., 2008).

A decrease in plant height subjected to water deficit is related to leaf primordia formation, which is a process that is sensitive to water restriction. The negative effects of water deficit on rice yield are due to low shoot and root biomass production, decreased soil nutrient utilization and decreased plant photosynthesis, which were both shown in this study and reported by Feng et al. (2012). A decrease in rice yield, growth and biomass was reported by Zain et al. (2014) and Nawaz et al. (2015) in rice and wheat plants subjected to water restrictions.

Selenium has beneficial effects on the growth of plants, especially in plants exposed to stress conditions. Strong growth of plants that received Se is related to improvements promoted by photosynthesis (Fig. 1) and by the decreased formation of reactive oxygen species, lipid peroxidation and formation of $\mathrm{H}_{2} \mathrm{O}_{2}$ in plant cells (Fig. 2B). Hashem et al. (2013) reported an increase in canola (Brassica napus L.) growth when the plants received foliar applications of 2.5 and $5.0 \mathrm{mg} \mathrm{L}^{-1} \mathrm{Se}$.

Drought stress is usually characterized by a reduction of chlorophyll and is associated with a progressive decline in the photosynthetic capacity of plants, which explains the lower SPAD values in plants experiencing water deficit compared to those of plants irrigated regularly. An increase of this index in plants under both water deficit conditions and Se treatment is associated with an increase in chlorophyll content, which is in agreement with the results of Iqbal et al. (2015). A decrease in SPAD index at the highest dose of Se is caused both by an adverse effect on porphobilinogen synthase production, which is necessary for chlorophyll biosynthesis, and the inhibition of biosynthetic enzymes through lipid peroxidation (Saffaryazdi et al., 2012).

An increase in $\mathrm{S}$ biomass accumulation in plants that were subjected to water deficit and that received doses of Se may be related to synergistic interactions between selenate and sulfate ions due to their similar chemical properties and use of the same membrane transporter and route of assimilation (Pilon-Smits, 2015; White, 2016). An increase in $S$ content in plants that received $1.0 \mathrm{~g} \mathrm{~kg}^{-1} \mathrm{Se}$ under water deficit conditions may have occurred because the stress promoted an increase in glutathione synthesis due to the need to reduce reactive oxygen species (Table 1). Se has a direct effect on enzyme synthesis. Thus, the synthesis requirement of Se for decreased S may have led to the accumulation of this element (N. Ahmad et al., 2016a; Sajedi et al., 2011). This accumulation was equal to that in plants under a normal water regimen at those doses.

The increase in $\mathrm{Cu}$ accumulation in rice plants due to Se doses differed from the results reported by Schiavon et al. (2013), who detected no effect on $\mathrm{Cu}$ accumulation in the shoots of tomato (Solanum lycopersicon L.). Arvy et al. (1995) reported increases in $\mathrm{Cu}$ in the biomass of Catharanthus roseus (L.) plants as a result of Se treatment. $\mathrm{Cu}$, $\mathrm{Fe}, \mathrm{Zn}$ and $\mathrm{Mn}$ are important SOD cofactors (Yao et al., 2013) that may have caused an increase in plant growth because of the high activity of the SOD enzyme (Fig. 2A).

The accumulation of nutrients in the shoots of rice plants under water deficit conditions decreased because of the reduction in mobility and absorption of nutrients. Under water stress conditions, roots are unable to absorb many nutrients from the soil due to decreased root activity, which is associated with decreased water movement toward the roots and slower ion diffusion (Alam, 1999). Sardans and Peñuelas (2004) reported that a $22 \%$ reduction in soil moisture decreased the amount of P accumulated in plants by $40 \%$; this reduction mainly occurred because there was no decrease in shoot biomass. In addition, Dejong and Phillips (1982) reported a decrease of 50\% in the accumulation of $\mathrm{N}$ in clover (Trifolium subterraneum L. cv. Woogenellup).

An increase in Se concentration in the shoots and grains of rice plants subjected to the application of this element was demonstrated by Hu et al. (2002), Boldrin et al. (2013), Hu et al. (2014) and Nothstein et al. (2016). This increase is related to the Se concentration mainly in the soil. The accumulation of Se in rice plant biomass is an important content predictor of this element in the seeds, as indicated in the study by Zhang et al. (2006) and confirmed in this present study.

In addition, the intended outcome of biofortification programs is an increase in Se concentration in plants and seeds without harming crop yield. In this regard, the doses applied in the present study did not promote a significant reduction in plant biomass or seeds. The results showed photosynthesis improvements and increased water use efficiency in plants subjected to water deficit, which demonstrates that Se is important for enhancing the development of plants under water deficit conditions.

\section{Conclusion}

Se application to rice plants improves their $\mathrm{CO}_{2}$ assimilation rate, 
transpiration rate, instantaneous carboxylation efficiency, water use efficiency estimation, and physiological capacity to withstand water deficit. There was a decrease in $\mathrm{H}_{2} \mathrm{O}_{2}$, and increases in SOD activity, accumulation of Se in shoot biomass and rice seeds due to applied Se doses. Further studies, should be developed under field conditions to establish suitable Se concentration in rice seeds for human consumption.

\section{Acknowledgments}

The authors would like to thank the National Council for Scientific and Technological Development, Brazil, Grant Number 448783/20142, and the Coordination of Higher Education Personnel Improvement (CAPES), Brazil, for their financial support and scholarship grant. ARR also thanks National Council for Scientific and Technological Development, Brazil, Grant Number 309380/2017 for the research fellowship.

\section{References}

Ahmad, N., Malagoli, M., Wirtz, M., Hell, R., 2016a. Drought stress in maize causes differential acclimation responses of glutathione and sulfur metabolism in leaves and roots. BMC Plant Biol. 16, 1-15. https://doi.org/10.1186/s12870-016-0940-z.

Ahmad, R., Waraich, E.A., Nawaz, F., Ashraf, M.Y., Khalid, M., 2016b. Selenium (Se) improves drought tolerance in crop plants - a myth or fact? J. Sci. Food Agric. 96, 372-380. https://doi.org/10.1002/jsfa.7231.

Alam, S.M., 1999. Nutrient uptake by plants under stress conditions. In: Pessarakli, M. (Ed.), Handbook of Plant and Crop Stress. Marcel Dekker, Inc, New York, pp. 285-313. https://doi.org/10.1201/9780824746728.ch12.

Aon, 2015. Annual global climate and catastrophe report: impact forecasting. Aon Global Privacy Office, Chicago, EUA.

Arvy, M.P., Thiersault, M., Doireau, P., 1995. Relationships between selenium, micronutrients, carbohydrates, and alkaloid accumulation in Catharanthus roseus cells. J. Plant Nutr. 18, 1535-1546. https://doi.org/10.1080/01904169509365002.

Biemelt, S., Keetman, U., Albrecht, G., 1998. Re-aeration following hypoxia or anoxia leads to activation of the antioxidative defense system in roots of wheat seedlings. Plant Physiol. 116, 651-658. https://doi.org/10.1104/pp.116.2.651.

Boldrin, P.F., Faquin, V., Ramos, S.J., Boldrin, K.V.F., Ávila, F.W., Guilherme, L.R.G., 2013. Soil and foliar application of selenium in rice biofortification. J. Food Compos. Anal. 31, 238-244. https://doi.org/10.1016/j.jfca.2013.06.002.

Buege, J.A., Aust, S.D., 1978. Microsomal lipid peroxidation. Methods Enzymol. 52, 302-310. https://doi.org/10.1016/s0076-6879(78)52032-6.

Dejong, T.M., Phillips, D.A., 1982. Water stress effects on nitrogen assimilation and frowth of Trifolium subterraneum L. using dinitrogen or ammonium nitrate. Plant Physiol. 69, 416-420. https://doi.org/10.1104/pp.69.2.416.

Djanaguiraman, M., Prasad, P.V.V., Seppanen, M., 2010. Selenium protects sorghum leaves from oxidative damage under high temperature stress by enhancing antioxidant defense system. Plant Physiol. Biochem. 48, 999-1007. https://doi.org/10. 1016/j.plaphy.2010.09.009.

Empresa Brasileira de Pesquisa Agropecuária - EMBRAPA, 1997. Manual de métodos de análise de solo, second ed. Ministério da Agricultura, Pecuária e do Abastecimento, Rio de Janeiro (in Portuguese).

Faize, M., Burgos, L., Faize, L., Piqueras, A., Nicolas, E., Alcobendas, R., Artlip, T., Hernandez, J.A., 2011. Involvement of cytosolic ascorbate peroxidase and $\mathrm{Cu} / \mathrm{Zn}$ superoxide dismutase for improved tolerance against drought stress. J. Exp. Bot. 62, 2599-2613. https://doi.org/10.1093/jxb/erq432.

FAO - Food and Agriculture Organization of the United Nations, 2017. Statistical Division. From: 〈http://faostat3.fao.org/〉 (Retrieved 25 June 2017).

Feng, F., Xu, X., Du, X., Tong, H., Luo, L., Mei, H., 2012. Assessment of drought resistance among wild rice accessions using a protocol based on single-tiller propagation and PVC-tube cultivation. Aust. J. Crop Sci. 6, 1204-1211.

Flexas, J., 2016. Genetic improvement of leaf photosynthesis and intrinsic water use efficiency in C3 plants: why so much little success? Plant Sci. 251, 155-161. https:// doi.org/10.1016/j.plantsci.2016.05.002.

Flexas, J., Medrano, H., 2002. Drought-inhibition of photosynthesis in C3 plants: stomatal and non-stomatal limitations revisited. Ann. Bot. 89, 183-189. https://doi.org/10. 1093/aob/mcf027.

Giannopolitis, C.N., Ries, S.K., 1977. Superoxide dismutases: I. Occurrence in higher plants. Plant Physiol. 59, 309-314.

Habibi, G., 2013. Effect of drought stress and selenium spraying on photosynthesis and antioxidant activity of spring barley. Acta Agric. Slov. 101, 31-39. https://doi.org/ 10.1104/pp.59.2.309.

Hashem, H.A., Hassanein, R. fa A., Bekheta, M.A., El-Kady, F.A., 2013. Protective role of selenium in canola (Brassica napus L.) plant subjected to salt stress. Egypt. J. Exp. Biol. 9, 199-211.

Havir, E.A., McHale, N.A., 1987. Biochemical and developmental characterization of multiple forms of catalase in tobacco leaves. Plant Physiol. 84, 450-455. https://doi. org/10.1104/pp.84.2.450.

Hu, Q., Chen, L., Xu, J., Zhang, Y., Pan, G., 2002. Determination of selenium concentration in rice and the effect of foliar application of Se-enriched fertiliser or sodium selenite on the selenium content of rice. J. Sci. Food Agric. 82, 869-872. https://doi.org/10.1002/jsfa.1115.

Hu, Y., Norton, G.J., Duan, G., Huang, Y., Liu, Y., 2014. Effect of selenium fertilization on the accumulation of cadmium and lead in rice plants. Plant Soil 384, 131-140. https://doi.org/10.1007/s11104-014-2189-3.

Iqbal, M., Hussain, I., Liaqat, H., Ashraf, M.A., Rasheed, R., Rehman, A.U., 2015. Exogenously applied selenium reduces oxidative stress and induces heat tolerance in spring wheat. Plant Physiol. Biochem. 94, 95-103. https://doi.org/10.1016/j.plaphy. 2015.05.012.

Jákli, B., Tavakol, E., Tränkner, M., Senbayram, M., Dittert, K., 2017. Quantitative limitations to photosynthesis in $\mathrm{K}$ deficient sunflower and their implications on wateruse efficiency. J. Plant Physiol. 209, 20-30. https://doi.org/10.1016/j.jplph.2016. 11.010 .

Jaleel, C.A., Manivannan, P., Wahid, A., Farooq, M., Al-Juburi, H.J., Somasundaram, R., Panneerselvam, R., 2009. Drought stress in plants: a review on morphological characteristics and pigments composition. Int. J. Agric. Biol. 11, 100-105.

Jiang, C., Zu, C., Lu, D., Zheng, Q., Shen, J., Wang, H., Li, D., 2017. Effect of exogenous selenium supply on photosynthesis, $\mathrm{Na}^{+}$accumulation and antioxidative capacity of maize (Zea mays L.) under salinity stress. Sci. Rep. 7, 42039. https://doi.org/10 1038/srep42039.

Joy, E.J.M., Broadley, M.R., Young, S.D., Black, C.R., Chilimba, A.D.C., Ander, E.L., Watts, M.J., 2015. Soil type influences crop mineral composition in Malawi. Sci. Total Environ. 505, 587-595.

Kumar, M., Bijo, A.J., Baghel, R.S., Reddy, C.R.K., Jha, B., 2012. Selenium and spermine alleviate cadmium induced toxicity in the red seaweed Gracilaria dura by regulating antioxidants and DNA methylation. Plant Physiol. Biochem. 51, 129-138. https:/ doi.org/10.1016/j.plaphy.2011.10.016.

Lambers, H., Chapin, F.S., Pons, T.L., 2008. Plant Physiological Ecology, second ed. Springer, Berlin. https://doi.org/10.1007/978-0-387-78341-3.

Mafakheri, A., Siosemardeh, A., Bahramnejad, B., Struik, P.C., Sohrabi, E., 2010. Effect of drought stress on yield, proline and chlorophyll contents in three chickpea cultivars. Aust. J. Crop Sci. 4, 580-585.

Malavolta, E., Vitti, G.C., Oliveira, S.A., 1997. Avaliação do estado nutricional das plantas: princípios e aplicações, second ed. Potafos, Piracicaba, SP, Brazil (in Portuguese).

Mostofa, M.G., Hossain, M.A., Siddiqui, M.N., Fujita, M., Tran, L.P., 2017. Phenotypical, physiological and biochemical analyses provide insight into selenium-induced phytotoxicity in rice plants. Chemosphere 178, 212-223. https://doi.org/10.1016/j chemosphere.2017.03.046.

Nakano, Y., Asada, K., 1981. Hydrogen peroxide is scavenged by ascorbate-specific peroxidase in spinach chloroplasts. Plant Cell Physiol. 22, 867-880. https://doi.org/10. 1093/oxfordjournals.pcp.a076232.

Nawaz, F., Ahmad, R., Ashraf, M.Y., Waraich, E.A., Khan, S.Z., 2015. Effect of selenium foliar spray on physiological and biochemical processes and chemical constituents of wheat under drought stress. Ecotoxicol. Environ. Saf. 113, 191-200. https://doi.org/ 10.1016/j.ecoenv.2014.12.003.

Nawaz, F., Naeem, M., Ashraf, M.Y., Tahir, M.N., Zulfiqar, B., Salahuddin, M., Shabbir, R.N., Aslam, M., 2016. Selenium supplementation affects physiological and biochemical processes to improve fodder yield and quality of maize (Zea mays L.) under water deficit conditions. Front. Plant Sci. 7, 1438. https://doi.org/10.3389/fpls. 2016.01438

Nothstein, A.K., Eiche, E., Riemann, M., Nick, P., Winkel, L.H.E., Gottlicher, J., Steininger, R., Brendel, R., Von Brasch, M., Konrad, G., Neumann, T., 2016. Tracking se assimilation and speciation through the rice Plant - Nutrient competition, toxicity and distribution. PLoS One 11, 1-15. https://doi.org/10.1371/journal.pone.0152081.

Pilon-Smits, E.A.H., 2015. Selenium in plants. In: Luttge, U., Beyschlag, W. (Eds.), Progress in Botany. Springer International Publishing, Switzerland, pp. 93-107. https://doi.org/10.1007/978-3-319-08807-5.

Proietti, P., Nasini, L., Del Buono, D., D’Amato, R., Tedeschini, E., Businelli, D., 2013 Selenium protects olive (Olea europaea L.) from drought stress. Sci. Hortic. (Amst.). 164, 165-171. https://doi.org/10.1016/j.scienta.2013.09.034.

R Development Core Team - RDCT, 2011. R: A Language and Environment for Statistical Computing. the R Foundation for Statistical Computing, Vienna, Austria (ISBN:3900051-07-0).

Reis, A.R., Favarin, J.L., Gratão, P.L., Capaldi, F. R., Azevedo, R.A., 2015. Antioxidant metabolism in coffee (Coffea arabica L.) plants in response to nitrogen supply. Theor. Exp. Plant Physiol. 27, 203-213.

Reis, A.R.D., El-Ramady, H., Santos, E.F., Gratão, P.L., Schomburg, L., 2017. Overview of selenium deficiency and toxicity worldwide: affected areas, selenium-related health issues, and case studies. In: Pilon-Smits, E.A.H., Winkel, L.H.E., Lin, Z.-Q. (Eds.), Selenium in Plants: Molecular, Physiological, Ecological and Evolutionary Aspects. Springer International Publishing, Cham, pp. 209-230.

Reis, H.P.G., Barcelos, J.P.Q., Junior, E.F., Santos, E.F., Silva, V.M., Moraes, M.F., Putti, F.F., Reis, A.R., 2018. Agronomic biofortification of upland rice with selenium and nitrogen and its relation to grain quality (doi.org/). J. Cereal Sci. 79, 508-515. https://doi.org/10.1016/j.jcs.2018.01.004.

Rosegrant, M.W., 2016. Challenges and policies for global water and food security. Econ. Rev. 5-20.

Saffaryazdi, A., Lahouti, M., Ganjeali, A., Bayat, H., 2012. Impact of selenium supplementation on growth and selenium accumulation on spinach (Spinacia oleracea L.) Plants. Not. Sci. Biol. 4, 95-100. https://doi.org/10.15835/nsb.4.4.8029.

Sajedi, N.A., Ardakani, M.R., Madani, H., Naderi, A., Miransari, M., 2011. The effects of selenium and other micronutrients on the antioxidant activities and yield of corn (Zea mays L.) under drought stress. Physiol. Mol. Biol. Plants 17, 215-222. https://doi. org/10.1007/s12298-011-0067-5.

Sander, B.O., Samson, M., Buresh, R.J., 2014. Methane and nitrous oxide emissions from 
flooded rice fields as affected by water and straw management between rice crops. Geoderma 235-236, 355-362. https://doi.org/10.1016/j.geoderma.2014.07.020.

Sardans, J., Peñuelas, J., 2004. Increasing drought decreases phosphorus availability in an evergreen Mediterranean forest. Plant Soil 267, 367-377. https://doi.org/10. 1007/s11104-005-0172-8.

Schiavon, M., Dall'Acqua, S., Mietto, A., Pilon-Smits, E.A.H., Sambo, P., Masi, A., Malagoli, M., 2013. Selenium fertilization alters the chemical composition and antioxidant constituents of tomato (Solanum lycopersicon L.). J. Agric. Food Chem. 61 10542-10554. https://doi.org/10.1021/jf4031822.

Shao, H., Chu, L., Shao, M., Jaleel, C.A., Hong, M., 2008. Higher plant antioxidants and redox signaling under environmental stresses. Comptes Rendus Biol. 331, 433-441. https://doi.org/10.1016/j.crvi.2008.03.011.

Silva, V.M., Boleta, E.H.M., Lanza, M.G.D.B., Lavres, J., Martins, J.T., Santos, E.F., Santos, F.L.M., Putti, F.F., Furlani Junior, E., White, P.J., Broadley, M.R., Carvalho, H.W.P., Reis, A.R.R., 2018. Physiological, biochemical and ultrastructural characterization of selenium toxicity in cowpea plants. Environ. Exp. Bot. 150, 172-182.

Silva Junior, E.C., Wadt, L.H.O., Silva, K.R., Lima, R.M.B., Batista, K.D., Guedes, M.C., Carvalho, G.S., Carvalho, T.S., Reis, A.R., Lopes, G., Guilherme, L.R.G., 2017. Natural variation of selenium in Brazil nuts and soils from the Amazon region. Chemosphere 188, 650-658.

Tardieu, F., Parent, B., Caldeira, C.F., Welcker, C., 2014. Genetic and physiological controls of growth under water deficit. Plant Physiol. 164, 1628-1635. https://doi. org/10.1104/pp.113.233353.

United States Environmental Protection Agency - USEPA, 1998. Method 3051 A: microwave assisted acid digestion of sediments sludges, soils and oils. In: Sw-846: Test Methods forEvaluation Solid Waste Physical and Chemical Methods. Office of Solid Waste. US. Environmental Protection Agency, Washington, pp. 1-20.
Velikova, V., Yordanov, I., Edreva, A., 2000. Oxidative stress and some antioxidant systems in acid rain-treated bean plants. Plant Sci. 151, 59-66. https://doi.org/10. 1016/S0168-9452(99)00197-1.

White, P.J., 2016. Selenium accumulation by plants. Ann. Bot. 117, 217-235. https://doi. org/10.1093/aob/mcv180.

Yan, W., Zhong, Y., Shangguan, Z., 2016. A meta-analysis of leaf gas exchange and water status responses to drought. Sci. Rep. 6, 20917. https://doi.org/10.1038/srep20917.

Yao, X., Chu, J., Wang, G., 2009. Effects of selenium on wheat seedlings under drought stress. Biol. Trace Elem. Res. 130, 283-290. https://doi.org/10.1007/s12011-0098328-7.

Yao, X., Jianzhou, C., Xueli, H., Binbin, L., Jingmin, L., Zhaowei, Y., 2013. Effects of selenium on agronomical characters of winter wheat exposed to enhanced ultravioletB. Ecotoxicol. Environ. Saf. 92, 320-326. https://doi.org/10.1016/j.ecoenv.2013.03. 024

Zain, N.A.M., Ismail, M.R., Puteh, A., Mahmood, M., Islam, M.R., 2014. Impact of cyclic water stress on growth, physiological responses and yield of rice (Oryza sativa L.) grown in tropical environment. Ciência Rural 44, 2136-2141. https://doi.org/10. 1590/0103-8478cr20131154.

Zhang, H., Li, D., Zhou, Z., Zahoor, R., Chen, B., Meng, Y., 2017. Soil water and salt affect cotton (Gossypium hirsutum L.) photosynthesis, yield and fiber quality in coastal saline soil. Agric. Water Manag. 187, 112-121. https://doi.org/10.1016/j.agwat.2017.03. 019.

Zhang, L., Shi, W., Wang, X., Zhou, X., 2006. Genotypic differences in selenium accumulation in rice seedlings at early growth stage and analysis of dominant factors influencing selenium content in rice seeds. J. Plant Nutr. 29, 1601-1618. https://doi. org $/ 10.1080 / 01904160600851437$. 